\title{
Multiscalar Ecological Characterization of Say's and Eastern Phoebes and their Zone of Contact in the Great Plains
}

Author(s): John M. Schukman, Andrés Lira-Noriega and A. Townsend Peterson

Source: The Condor, 113(2):372-384. 2011.

Published By: Cooper Ornithological Society

URL: http://www.bioone.org/doi/full/10.1525/cond.2011.100073

BioOne (www.bioone.org) is a nonprofit, online aggregation of core research in the biological, ecological, and environmental sciences. BioOne provides a sustainable online platform for over 170 journals and books published by nonprofit societies, associations, museums, institutions, and presses.

Your use of this PDF, the BioOne Web site, and all posted and associated content indicates your acceptance of BioOne's Terms of Use, available at www.bioone.org/page/terms of use.

Usage of BioOne content is strictly limited to personal, educational, and non-commercial use. Commercial inquiries or rights and permissions requests should be directed to the individual publisher as copyright holder. 


\title{
MULTISCALAR ECOLOGICAL CHARACTERIZATION OF SAY'S AND EASTERN PHOEBES AND THEIR ZONE OF CONTACT IN THE GREAT PLAINS
}

\author{
John M. Schukman ${ }^{1,3}$, Andrés Lira-Noriega ${ }^{2}$, And A. Townsend Peterson ${ }^{2}$ \\ ${ }^{1} 14207$ Robin Road, Leavenworth, KS 66048 \\ ${ }^{2}$ Natural History Museum and Biodiversity Research Center, University of Kansas, \\ Lawrence, KS 66045
}

\begin{abstract}
We assessed interspecific ecological relationships between Say's (Sayornis saya) and Eastern (S. phoebe) phoebes at three scales by developing ecological niche models at two spatial extents and comparing the models' predictions with data from local-scale surveys. The two species' habitats differed in several environmental attributes, primarily precipitation, temperature, and vegetation indices, at both extents. Local-scale surveys between $-97^{\circ}$ and $-101^{\circ}$ longitude revealed a steep gradation in ratios of occurrences Say's to the Eastern Phoebe, increasing from east to west. Local-scale occurrences coincided with results of ecological niche models at the extent of both the continent and contact zone, except for Eastern Phoebe occurrences and vegetation indices at both extents. Say's Phoebes nested in open country with sparse or no surrounding woodland, whereas Eastern Phoebe nests were primarily along woodland streams but also at seven sites in more open country where Say's Phoebes had nested previously. At the contact-zone extent, the niche space of the Eastern Phoebe was embedded more into that of Say's Phoebe than the converse. Although niche models at the contact-zone extent indicated some potential for contact, competition between these two species for nest sites is probably less important in limiting distributions than are autoecological characteristics.
\end{abstract}

Key words: $\quad$ contact zone, ecological niche models, Great Plains, niche overlap, Sayornis phoebe, Sayornis saya.

Caracterización Ecológica en Múltiples Escalas de Sayornis saya y S. phoebe y su Zona de Contacto en las Grandes Planicies

Resumen. Se propuso analizar la relación interespecífica entre Sayornis saya y S. phoebe a tres escalas mediante modelos de nicho ecológico (MNE) considerando dos extensiones espaciales de análisis, y comparar las predicciones de los modelos con datos a escala local. Las dos especies mostraron diferencias en sus atributos ambientales para ambas extensiones, principalmente con relación a precipitación, temperatura e índices de vegetación. Los muestreos a escala local, entre $\operatorname{los}-97^{\circ}$ y $-101^{\circ}$ de longitud, mostraron un incremento dramático de este a oeste en la proporción de ocurrencias de $S$. saya con respecto a $S$. phoebe. Las ocurrencias de $S$. saya a escala local coincidieron con las predicciones del MNE para ambas extensiones de análisis, salvo para S. phoebe a ambas escalas, con relación a los índices de vegetación. Los sitios de anidación de $S$. saya se encontraron con mayor frecuencia en zonas abiertas con vegetación leñosa esparcida o sin ella; los sitios de anidación de $S$. phoebe fueron encontrados a lo largo de arroyos con vegetación leñosa, pero también en siete localidades en zonas más abiertas donde $S$. phoebe había anidado previamente. En la zona de contacto, el espacio del nicho ecológico de $S$. phoebe estuvo más inmerso dentro del espacio de nicho de $S$. saya que lo contrario. A pesar de que los MNE para la extensión de zona de contacto muestran un contacto interespecífico potencial, la competencia interespecífica por sitios de anidación entre estas dos especies tiene probablemente menos importancia en limitar las distribuciones que la autoecología de cada especie.

\section{INTRODUCTION}

The Great Plains of central North America provide opportunities for pairs of closely related species that replace each other from east to west to approach spatially and form contact zones or hybrid zones. These species pairs, best documented among birds, come into secondary contact under varying circumstances. Assessing factors that influence contact-zone associations could provide a better understanding of modes of speciation, vicariance, pre- and post-glacial distributions, responses to habitat changes, climatic changes, and competitive interactions (Emlen et al. 1975, Mayr and O'Hara 1986, Dixon 1989, Rising 1996, Peterson 2003, Swenson 2006). Generally, such secondary contact can produce results ranging from minor

Manuscript received 12 April 2010; accepted 6 October 2010.

${ }^{3}$ E-mail: schuksaya@kc.rr.com

The Condor, Vol. 113, Number 2, pages 372-384. ISSN 0010-5422, electronic ISSN 1938-5422. @ 2011 by The Cooper Ornithological Society. All rights reserved. Please direct all requests for permission to photocopy or reproduce article content through the University of California Press's Rights and Permissions website, http://www.ucpressjournals.com/ reprintInfo.asp. DOI: $10.1525 /$ cond.2011.100073 
geographic variants to stable hybrid zones and full speciation (Mayr and O’Hara 1986). Before modern human settlement the Great Plains constituted a barrier that precluded most east-west contact of forest birds, but more recently, particularly thanks to the appearance of human-altered landscapes, a broader spread of woodland habitat has allowed range expansion (Ehrlich et al. 1988). Expansion may be asymmetrical, where one form spreads in one direction at a rate different from that of its counterpart in reverse (Mayr and O'Hara 1986). These species pairs may interact, with competition possibly influencing distributional limits (Rising 1983, Dixon 1989, Swenson 2006). Assessing historical shifts in distributions due to climate and vegetation change could provide insight into future distributions as well.

The Say's (Sayornis saya) and Eastern (S. phoebe) phoebes, a species pair not listed by Ehrlich et al. (1988) and overall little studied, overlap across much of the central and northern Great Plains, where their breeding ranges reach their respective eastern and western range limits (AOU 1998). Rare hybrids between the two are known, as well as hybrids of each with a third species, also western, the Black Phoebe (S. nigricans; Cook 1984, Pieplow et al. 2008; Rob Fowler, pers. comm.). Dixon (1989) recognized these phoebes as possibly coming into contact, but their distributions do not overlap in Texas.

Typical sites of Say's Phoebe nests are in open country (Schukman and Wolf 1998), whereas Eastern Phoebe nests are generally in woodland or edge habitats, often near water (Weeks 1994). Phoebes require a particular configuration of surfaces to support nests and provide protection overhead. They appear to select nest sites preemptively: once a site is occupied, other phoebes are prevented from nesting there (McPeek et al. 2001). Natural nest sites include cliffs and caves, but human-made structures (buildings and bridges) provide many additional nest sites for both species, which has permitted geographic and population expansion (Weeks 1994, Schukman and Wolf 1998). The Breeding Bird Survey (BBS) suggests increases in both species' population from 1966 to 2007 in the High Plains Border physiographic province and the central BBS region (Sauer et al. 2008). In Nebraska, Sharpe et al. (2001) presented evidence that Say's Phoebe expands eastward during intermittent dry cycles; in Oklahoma, it has expanded eastward in the Panhandle in the last 20 years (Reinking 2004), and east of the Panhandle breeding was first confirmed in 2003 (Schukman 2004). In central and western South Dakota, Rumble et al. (1998) attributed westward expansion of the Eastern Phoebe to building of bridges and possible expansion into open woodland. However, potential nest sites are limited, and interspecific competition for nest sites may arise in habitat transitional between woodland streams and open country in west-central Kansas (Schukman 1993). In North Dakota, Say's Phoebes have nested along woodland streams where Eastern Phoebes are more expected (Stewart 1975).
The broad area of co-occurrence, increases in abundance, prospects of range expansion, evidence suggesting competition, evidence of hybridization, spread of deciduous trees because of human alteration of stream flows (Knopf and Scott 1990), spread of invasive woody plants (Coppedge et al. 2001), changes in agroforestry (Bratton et al. 1995), and anticipated shifts in response to climate change (Peterson 2003) raise the question of how the balance between the earlier-nesting Eastern Phoebe and the xeric-adapted Say's Phoebe might shift in coming decades. Ecological niche models (ENMs) have been used to assess relationships between closely related species (Peterson et al. 1999), particularly between pairs of species that replace each other along environmental gradients on the Great Plains (Swenson 2006, Costa et al. 2008). Anderson et al. (2002) showed that ENMs could be used as a predictive tool to detect and characterize possible competitive relationships. Cunningham et al. (2009) used ENMs on broad scales, complemented with fine-scale studies of biotic interactions across contact zones, to evaluate how abiotic and biotic interactions affect the spatial distribution of species of salamanders.

Although the two phoebes' habitat preferences are generally distinct, the amount of niche overlap and factors limiting their overall distributions are not well known. Therefore, analyses of niche relationships in areas of sympatry and allopatry may provide insight into limits imposed by environmental factors, competition, niche conservatism, and climate change. In this study, we aim to assess the ecological distribution of each species (1) across the continent, (2) in areas close to the area of contact, and (3) at a local scale within the contact zone. The results offer insight into factors controlling the distributions of this species pair.

\section{METHODS}

\section{EXTENTS OF ANALYSIS AND INPUT DATA}

We concentrated on three extents of analysis to assess ecological characteristics of the two phoebes: (1) continent-wide across the contiguous 48 United States, (2) a contact zone 800 $\mathrm{km}$ wide between approximately $-104^{\circ}$ and $-96^{\circ} \mathrm{W}$ longitude, centered on the limits of the two species, and (3) local nesting sites in a longitudinal transect perpendicular to the contact zone in western Kansas (Fig. 1). To compare and contrast these scales of analysis, we used two sources of occurrence data, localities from the BBS for extents (1) and (2) and independent, fine-resolution observations in the field for extent (3) (see below). We drew the $800-\mathrm{km}$ buffer of analysis that corresponds to scale (2) with reference to the line of coincidence of the BBS occurrence points of the two species. The coordinates from the BBS correspond to the start of the routes. Using this central axis, we drew two parallel lines toward the east and west at a distance of $400 \mathrm{~km}$ each. To characterize environments, we used three sources of data: (1) seven relatively uncorrelated (mean $r=0.5 \pm$ SD 0.3) "bioclimatic" variables (annual 
(a)
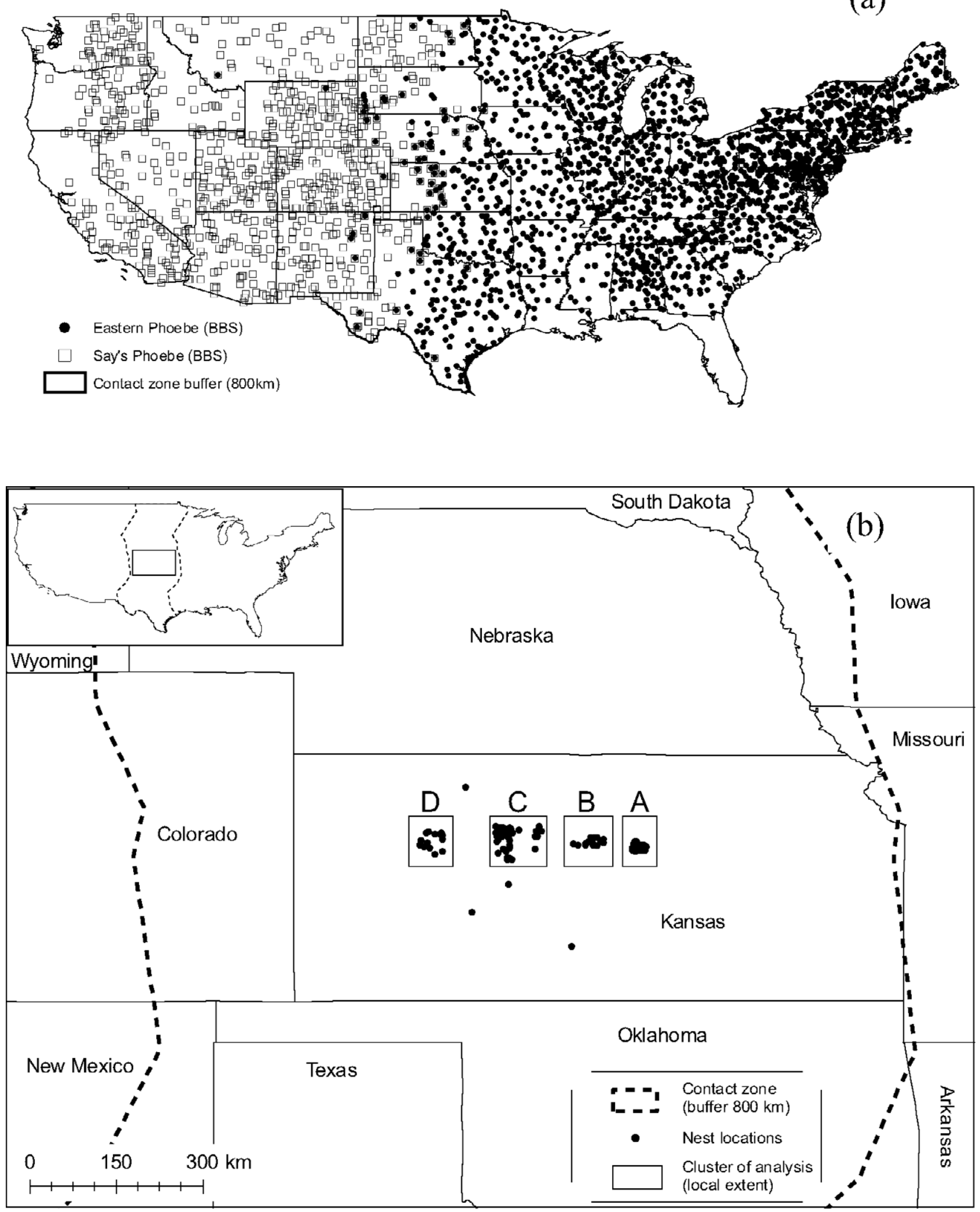

FIGURE 1. Study area and scales of analysis: (a) continentwide, showing contact zone between $-104^{\circ}$ and $-96^{\circ} \mathrm{W}$ longitude ( $\sim 800 \mathrm{~km}$ wide), and (b) the local survey of nesting sites of the Say's and Eastern Phoebes. Occurrence data available are plotted on each map. 
mean temperature, mean diurnal temperature range, maximum temperature of the warmest month, minimum temperature of the coldest month, annual precipitation, precipitation of the wettest month, precipitation of driest month) and elevation at a resolution of $\sim 1 \mathrm{~km}^{2}$ (http://www.worldclim.org/; Hijmans et al. 2005); (2) enhanced vegetation indices (EVI) from 12 monthly composite (every second image) MODIS satellite images(http://modis.gsfc.nasa.gov/) from 2003 and 2004 at a resolution of $250 \mathrm{~m}$; and (3) land use and habitat physiognomy recorded during direct field observations (see below).

\section{ENVIRONMENTAL AFFINITIES AND ECOLOGICAL NICHE MODELING}

We first characterized longitudinal patterns of the mean and variance of the bioclimatic variables and elevation across the study area via a $0.5^{\circ} \times 0.5^{\circ}$ grid, as well as the modeled habitat suitability from the ENM (see below) for the two phoebes on the same grid. To characterize the environmental affinities of each species better at the continental and contact-zone extents, we transformed the respective ecological spaces by principal components analysis based on a correlation matrix of the seven bioclimatic variables and elevation at a resolution of $\sim 1 \mathrm{~km}^{2}$. We then plotted the principal components coordinates of each species to analyze similarities by using an equal number of points of unique occurrence of each species (continental extent, $n=864$; contact zone, $n=206$; sample sizes set as the smaller of the samples of the two species, subsets chosen randomly).

For each species, we developed four sets of ENMs to interpret environmental requirements at the two broader extents of study. The models correspond to the environmental data and scale as follows: MODIS (EVI) $\times$ continent, MODIS $(\mathrm{EVI}) \times$ contact zone, climate - elevation $\times$ continent, and climate-elevation $\times$ contact zone.

To evaluate ecological niche overlap, we used two metrics, the Hellinger's-based $I$ and Schoener's $D$ as implemented by Warren et al. $(2008,2010)$ in the freely available software ENMTools (http://enmtools.com/). These metrics summarize the similarity of predictions of habitat suitability by values ranging from 0 (no overlap) to 1 (equally suitable); details of these measures are provided in Warren et al. (2008). For the continental and contact-zone extents, we applied such measurements in comparison with a background-similarity randomization to determine whether the two species were more or less similar than expectated from differences in the environmental background where they occur. We used the same occurrence data, as implemented in ENMTools, for the continent and contact zone areas as described above (see details below). We used a buffered (buffer equivalent to $25 \%$ of the longest axis) minimum convex polygon around known occurrences for each species for its corresponding continent and contact-zone distributions, as a hypothesis of dispersal capabilities, from which we sampled background points (see
Soberón and Peterson 2005, Anderson and Raza 2010). We focused on a null hypothesis that the two species' distributions were not more different than expected by chance. We ran this procedure eight times, permitting comparison of Say's Phoebe occurrences to the background of the Eastern Phoebe and vice versa, at the two broadest scales of analysis, for each of the two environmental data sets.

We also tested for the existence of a linear environmental break along the contact zone between the two species (Warren et al. 2010). Using ENMTools, we tested whether the overlap of the ENMs for the pair of species was different from random after splitting the occurrence data into the same proportions as in the actual occurrence data with a randomly oriented line. This procedure allowed comparison of the observed measurements of overlap against a distribution of overlaps drawn at random both for the contact-zone area and the continental extent. We tested the null hypothesis that the line separating the two species was not associated with any zone of particular environmental differentiation.

In both sets of comparisons detailed above, ENMTools generates ENMs with Maxent (Phillips et al. 2006). We developed 1000 replicates for each comparison to generate the null distributions. In each replicate, the occurrence data were split randomly to generate the niche models, and the corresponding overlap measures $I$ and $D$ were calculated. We used the default settings (perforce in ENMTools) in Maxent, except that we used $50 \%$ of the occurrence data for training and $50 \%$ for testing.

For more qualitative comparisons, and for comparisons of geographic predictions, we developed ENMs with the Genetic Algorithm for Rule Set Prediction (GARP) (Stockwell and Peters 1999), which performs equivalently to, but offers much easier interpretation than, models from the more popular Maxent (Peterson et al. 2007). We used GARP version 1.1.6, publicly available at http://www.nhm.ku.edu/desktopgarp/. GARP is an evolutionary-computing method that builds ENMs on the basis of nonrandom associations between points of species' known occurrence and sets of GIS coverages describing the ecological landscape, and it develops "models" presenting optimal discrimination between presence and pseudoabsence records via sequential approximations resembling chromosomal evolution. Within GARP's processing, 50\% of occurrence data records were used as test points ("extrinsic testing data"; see below), $25 \%$ were used to train models, and the remaining $25 \%$ were used in model refinement and calibration.

Following best-practices recommendations (Anderson et al. 2003), we developed 100 replicate random-walk GARP models, then discarded $90 \%$ by considering error statistics, as follows. This consensus method consists of an initial filter removing models that omit (omission error $=$ predicting absence in areas of known presence) heavily on the basis of extrinsic testing data and a second filter based on an index-ofcommission error (= predicting presence in areas of known absence, estimated simply as the proportion of the region of 
analysis predicted as suitable), in which models predicting very large and very small areas were removed from consideration. Specifically, in DesktopGARP, we used a soft omission threshold of $20 \%$ and $50 \%$ retention based on commission considerations; the result was 10 binary predictions that we summed to generate a raster map with cells valued from 0 (no model predicts presence in the cell) to 10 (all models predict presence). We generally took as a final "best" prediction for each species the area of complete coincidence of prediction of potential for presence, but we show the rest of the values for interpretation.

\section{LOCAL ASSESSMENT}

During the breeding seasons of 2004, 2005, 2006, and 2008 (one observation of nest-site reversal from 2010), at the local scale, JMS searched for nest sites of Say's and Eastern phoebes along latitude $39^{\circ} \mathrm{N}$ in four distinct longitudinal clusters: (A) $-97.76^{\circ}$ to $-97.91^{\circ}$, (B) $-98.28^{\circ}$ to $-98.64^{\circ}$, (C) $-99.06^{\circ}$ to $-99.59^{\circ}$, and (D) $-100.13^{\circ}$ to $-100.98^{\circ}$. The landscape, in the Smoky Hills area of west-central Kansas, consisted primarily of mixed-grass prairie, interspersed with rock outcrops and cultivated land; native woodland was limited to the edges of permanent and intermittent streams (Kuchler 1974). A geographic positioning system (GPS) was used to determine coordinates of nest sites $(n=147)$, primarily at public bridges $(n=$ $127)$, but also at some abandoned buildings $(n=17)$ and, rarely, at rock bluffs $(n=3)$. Most $(n=119)$ sites were confirmed as nest sites, but some were only probable, based on presence of singing males. Bridges become scarcer or less suitable for phoebes in upper reaches of drainage basins and farther west. These unsuitable bridges or structures were either built low to the ground or were constructed of circular metal tubes or concrete slabs directly on the ground. Toward the west, as the density of roads, bridges, and human structures decreased, we surveyed larger areas, which required more time to yield adequate sample sizes. We recorded information on fine-scale distribution and reuse of nest sites from still more detailed searches within cluster C (Ellis County; Fig. 1), where both phoebes were known to have nested previously (Schukman 1993), and from observations by others in western Kansas (Pratt County, 2003; Rush County, 2005; Norton County, 2005; Russell County, 2003; see Acknowledgments).

\section{RESULTS}

\section{CONTINENTAL AND CONTACT-ZONE SCALES}

Several environmental measurements varied dramatically with longitude across the continent; patterns of change in the contact zone indicated abrupt changes in some of the environmental variables (Fig. 2). The steepest gradients associated with the contact zone were in elevation, mean annual precipitation, mean diurnal range of temperature, and mean precipitation of the driest month, but change to some degree coincident with the contact zone was observed in all of the variables (Fig. 2). Principal components analysis showed that each species occupied a space defined by a distinct combination of environmental measures. In the environmental space depicted by the first two principal components, which accounted for $84 \%$ of the overall variation, the two species overlapped to different degrees: less at the continental extent and more at the contact-zone extent (Fig. 3).

The maps derived from the ENMs offered information complementary to the two preceding analyses of longitudinal environmental variation. The models using vegetation indices as predictors showed greater possibility of overlap of the two species than did those based on bioclimatic variables, which had more clearly defined limits between the species (Fig. 4); this difference was especially evident in analyses at the contact-zone extent. The use of these two sets of variables makes evident the potential advantages of vegetation indices, which are available at a spatial resolution much higher and with a more complicated spatial pattern than are climatic variables (see also Figs. 2 and 5).

In quantitative comparisons, the two species showed clear differences in environmental affinities at the contact-zone extent (overlap measurements: $I=0.527, D=0.279$ ) and the continental extent (overlap measurements: $I=0.436, D=0.155$ ), both measured in the space of the bioclimatic variables (Figs. $2-4)$. The background-similarity tests indicated that the two species had different climate and habitat requirements, even when differences in the environmental context in which each is distributed were taken into account $(P<0.01)$. In tests designed to detect an environmental boundary separating the two species along the contact zone at the continental scale, no indication of difference was noticeable, but some signal was apparent in tests within the contact zone only: the linear-break test did not suggest a clear linear separation of environments between the two species $(P>0.01)$, except for the test based on the Schoener's $D$ statistic at the contact-zone scale $(P<0.01)$.

\section{LOCAL SCALE}

The proportion of Say's Phoebe occurrences out of the total number of phoebes increased from east to west in the localscale surveys: (A) $0 \%$, (B) $16.7 \%$, (C) $46.7 \%$, and (D) $56.7 \%$ ( $n=33,24,60$, and 30 nest sites, respectively; Fig. 1). Results of local-scale surveys of Say's Phoebe were consistent with ENM predictions at both extents of both sets of variables (Fig. 5), this species being absent or rare in the two eastern clusters but more abundant in the two western clusters. Local-scale surveys of the Eastern Phoebe also were consistent with some ENM predictions: decrease in density to the west in models based on climatic factors (Fig. 5). In contrast, ENMs based on EVI variables produced a broader, more detailed prediction at the contact-zone extent (Fig. 5).

Most Eastern Phoebes nested along primary and secondary streams, only infrequently along tertiary streams. Say's Phoebe nest sites, on the other hand, were located on secondary 

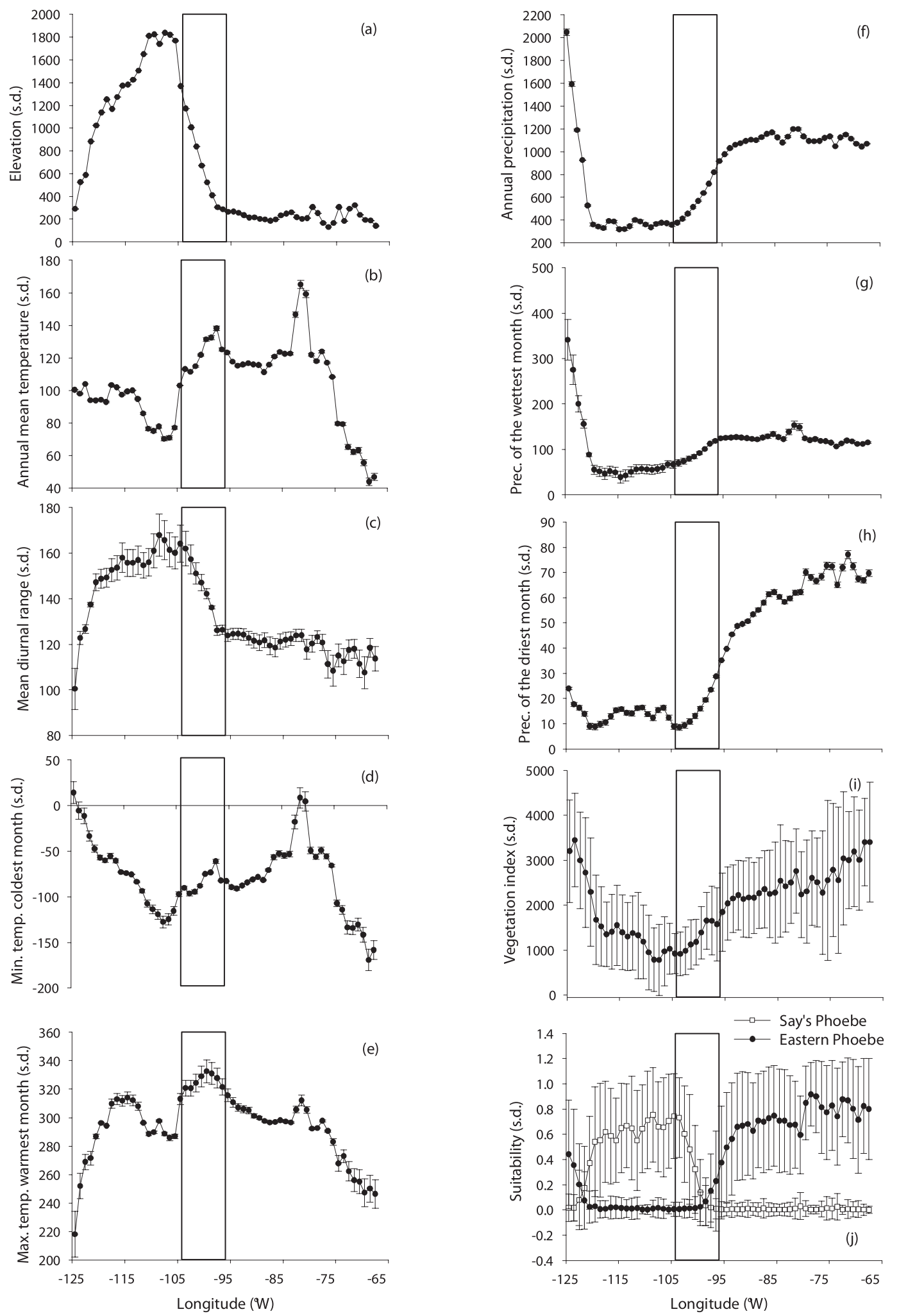

FIGURE 2. Longitudinal variation (average $\pm \mathrm{SD}$ ) of environmental variables used in the analysis (panels $\mathrm{a}-\mathrm{i}$ ) and the predicted environmental combinations suitable for each species (j), measured across the contiguous 48 United States on a $0.5^{\circ} \times 0.5^{\circ}$ grid. The black rectangle represents the $800-\mathrm{km}$-wide contact zone used for the analysis of the two species. The standard deviation bars corresponding to some means are too small to be seen. See Methods for detailed explanation of these calculations. 


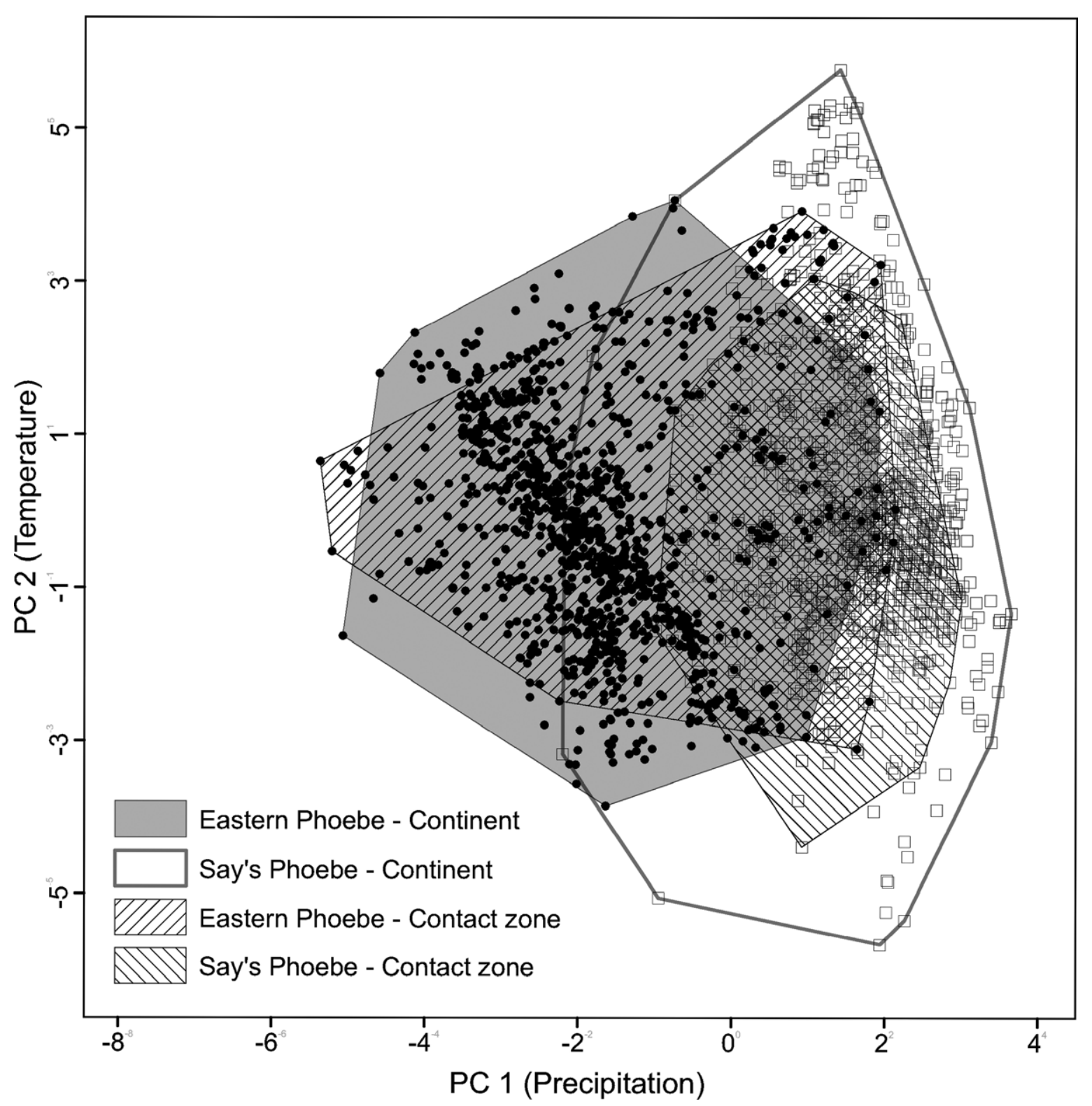

FIGURE 3. Environmental combinations extracted from the first two principal components for the Eastern and Say's phoebes. Principal components 1 and 2 account for $50 \%$ and $34 \%$ of the variation of the environmental data, respectively. From the loadings, the main variables defining the first principal component are annual precipitation, precipitation of the wettest month, precipitation of the driest month, and elevation. Principal component two is composed mostly of annual mean temperature, maximum temperature of the warmest month, and minimum temperature of the coldest month.

and tertiary streams, as well as in more open country. Both species occurred at the same site at seven locations in different years, and at one site in the same breeding season. Eastern Phoebes last occupied seven sites ( 9 May 2005, $n=4 ; 26$ June 2004, $n=1$; 29 June 2004, $n=1$; 15 May 2010, $n=1$ ) previously used (i.e., before 1993; Schukman 1993) by Say's Phoebes, whereas Say's Phoebes last occupied only one site (9 May 2005) previously used by Eastern Phoebes. Both species nested simultaneously at the same nest site (in cluster C, Fig. 1) in 2005, a rare observation: the nests were $\sim 5 \mathrm{~m}$ apart, on opposite sides of separate steel I-beams supporting a bridge, $\sim 2 \mathrm{~m}$ from the ground. Young from each pair's first brood were banded on the same day (G. Farley, pers. comm.) and recently fledged Say's Phoebe young were observed there at a later date (S. Nilz, pers. comm.). We noted no other interactions between the two species during any of our nest-site observations.

These phoebes' using the same nest sites in different years also been reported from Rush, Norton, Pratt, and Russell counties, Kansas (S. Seltman, K. Brunson, M. Rader, M. B. Robbins, pers. comm.). Both species were observed in the 


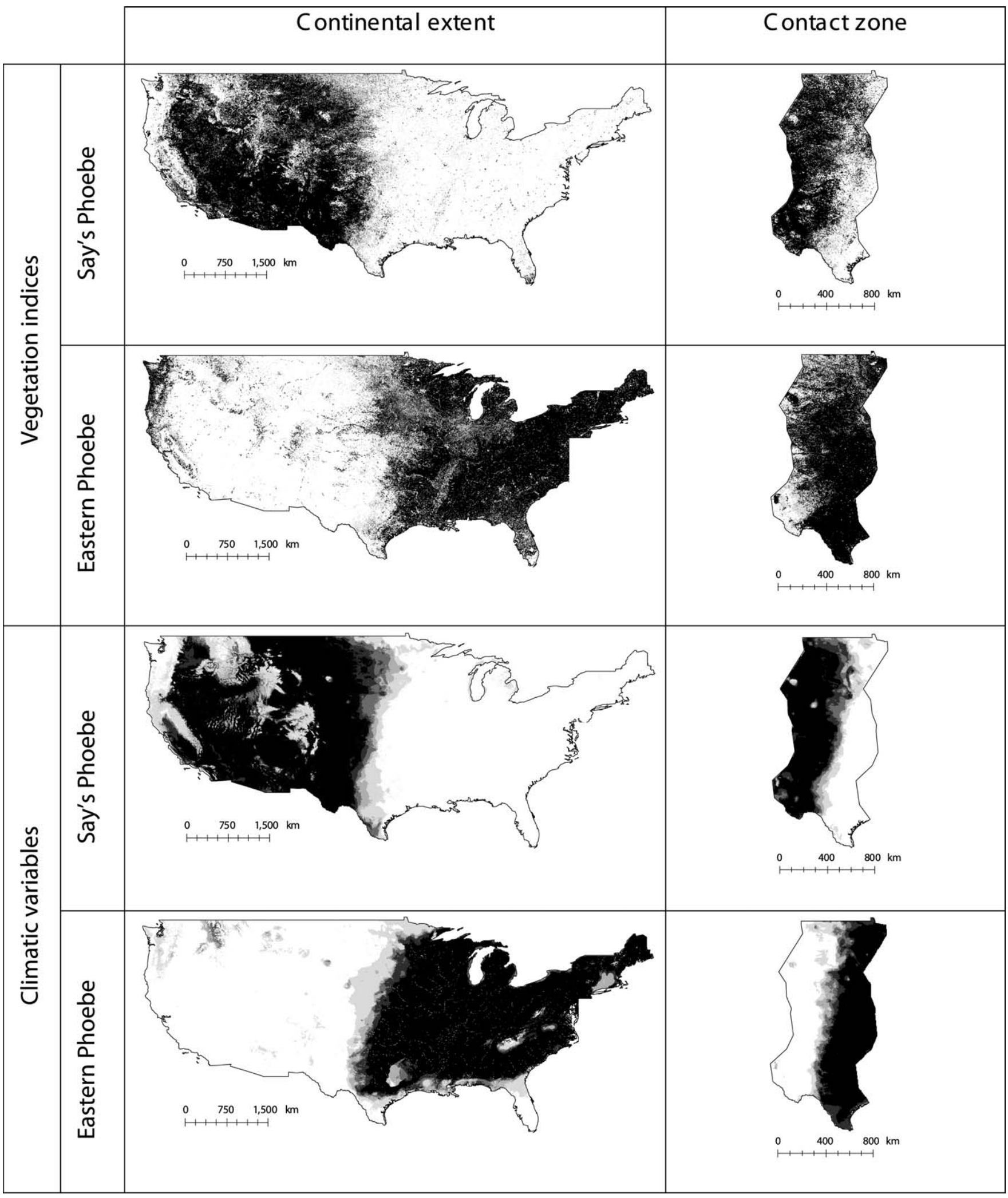

FIGURE 4. Ecological niche models of the Eastern Phoebe and Say's Phoebe for the two sets of predictor variables (vegetation indices and climatic variables) across the conterminous United States and the contact zone, as based on balanced sets of occurrence points. Black indicates high suitability, light gray low suitability, and white unsuitability. 


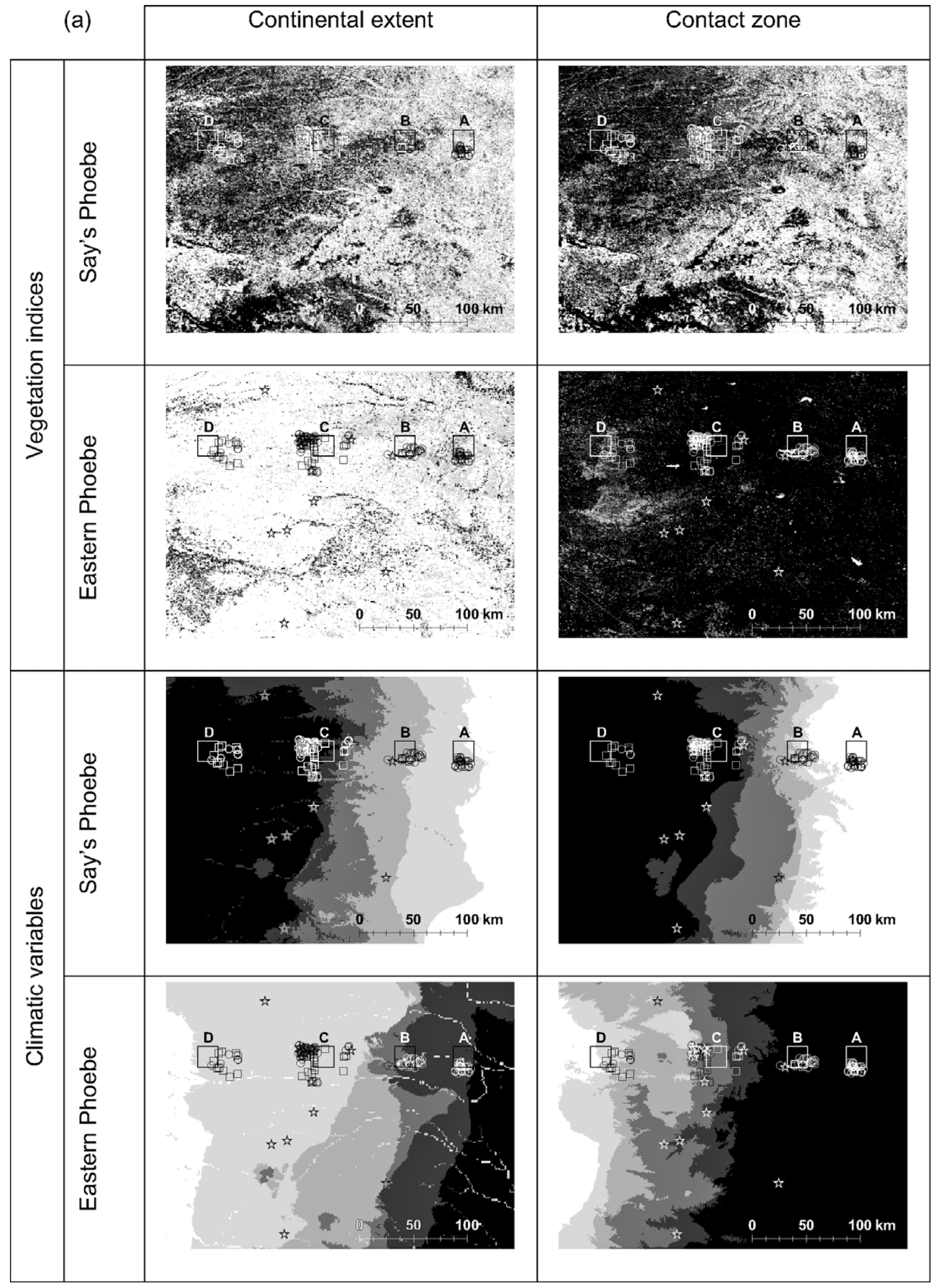

FIGURE 5. (a) Closer view of the geographic projections of the ecological niche models of the Eastern Phoebe and Say's Phoebe for the two sets of predictor variables (vegetation index and bioclimatic variables) in the region of local assessment. Black indicates high suitability, light gray low suitability, and white unsuitability. Corresponding mean values of the habitat conditions at the nest sites in clusters A-D predicted from vegetation indices for Say's and Eastern Phoebes at the (b) continent and (c) contact-zone extents. 

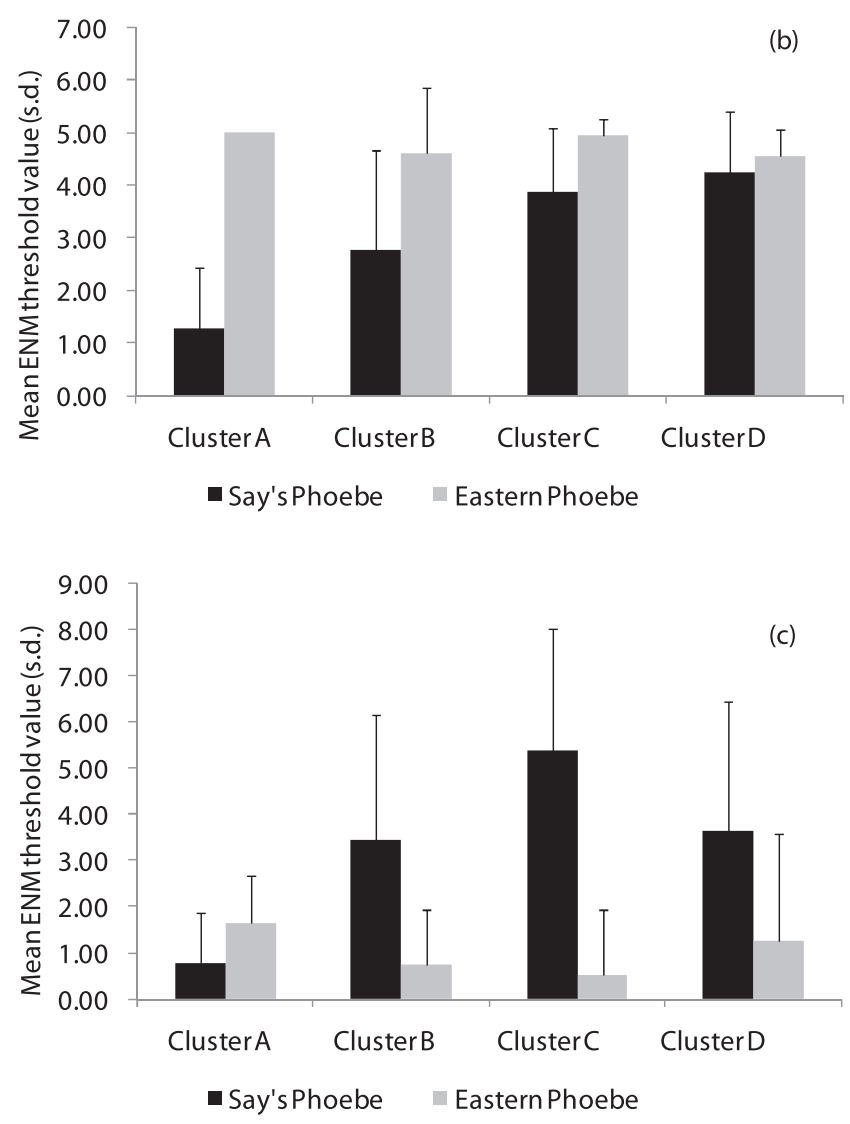

FIGURE 5. Continued.

same season on a farm in Rush County, Kansas: the Eastern Phoebes had a nest, but it is unknown if the Say's Phoebes nested (S. Seltman, pers. comm.).

\section{DISCUSSION}

At the continental scale, ENMs showed precipitation and temperature variables for the two species of phoebes as differing, with precipitation factors changing more steeply within the contact zone itself. Although environmental conditions within the geographic range of each species vary, trends in indices of suitability for both species changed dramatically near and within the contact zone. This result is consistent with the general habitat differences of Say's and Eastern phoebes in terms of use of open country versus forest or edge, respectively; however, background-similarity tests indicate that these differences are not simply a consequence of living in different areas with different environments. That is, the distinct environments used by each species appear to reflect real differences in use of the environment rather than environmental differences specific to each species' range.

Some of the scattered and isolated predictions in some of the models, such as the EVI predictions of suitable areas for Eastern Phoebes throughout the western half of the United States, coincide with records of Eastern Phoebe nesting and the origin of Black $\times$ Eastern Phoebe hybrids in Larimer, Pueblo (Pieplow et al. 2008), and Fremont (SeEtta Moss, pers. comm.) counties, Colorado. As climate data are simpler and more autocorrelated, ENMs based on climatic variables did not predict sites for the Eastern Phoebe in the western half of the continent at this fine scale.

Within the contact zone, ENM predictions based on EVI and climatic variables for Say's Phoebe were mostly consistent with BBS data (Sauer et al. 2008) and atlases (Peterson 1995, Kingery 1998, Busby and Zimmerman 2001, Mollhoff 2001). Generally, occurrences increase from east to west, with low numbers in the eastern Dakotas, eastern Nebraska, and central Kansas. However, the ENM also predicted appropriate conditions in western Oklahoma and north-central Texas, where this species is not known to breed (Schukman and Wolf 1998). ENM predictions for the Eastern Phoebe based on climatic variables within the contact zone showed suitability for occurrence decreasing from east to west and contrasted with more extensive predicted coverage across the contact zone when models were based on EVI. At both scales, however, the models showed limits to the west, and the causal factors behind those limits need to be explored. Even though it was not clear whether a significant boundary exists between the two species according to the linear-break test and the corresponding ENM comparisons (i.e., we could not reject the null hypothesis of no linear break about the position of the contact zone), we observed some signal of a break at the contact-zone extent. According to the background analysis, however, it is clear that each species has different environmental requirements.

Swenson (2006) asserted that temperature was the unifying factor maintaining hybrid zones across the Great Plains in four pairs of taxa. He suggested that eastern species are heatstressed at their western boundaries but that western species are not. For example, the Baltimore Oriole (Icterus galbula), an eastern species, appears to be physiologically limited to the west because its realized distribution coincides with its potential, whereas Bullock's Oriole (I. bullockii) is probably excluded competitively from the east because its distribution is confined to the Great Plains but its potential extends more broadly into eastern states (Swenson 2006). This reasoning might suggest, in the present case, that the Eastern Phoebe is limited abiotically to the west, whereas Say's Phoebe is competitively excluded from the east, but further study is needed.

We trained ENMs at the contact-zone scale to assess effects of occurrences in areas of parapatry or sympatry to those in areas of allopatry and to account for regional niche variation (Murphy and Lovett-Doust 2007). ENMs based on the contact zone showed overlap of the Eastern Phoebe into the Say's Phoebe's niche space but not as much as of the converse; this pattern is clearest in climate-based models. The 
western limit of the Eastern Phoebe in the ENMs coincided well with that of several eastern species, the Baltimore Oriole, Indigo Bunting (Passerina cyanea), Rose-breasted Grosbeak (Pheucticus ludovicianus), and Yellow-shafted Flicker (Colaptes auratus auratus subspecies group). However, the eastern limit of Say's Phoebes contrasts with that found by Swenson (2006) for other western species, Bullock's Oriole, Lazuli Bunting (Passerina amoena), Black-headed Grosbeak (Pheucticus melanocephalus), and Red-shafted Flicker ( $C$. auratus cafer subspecies group): the modeled eastern limit for Say's Phoebe was within the Great Plains, whereas Swenson's models for the other western species showed extensive potential for occurrence in the eastern part of the continent. Still, interpretation of the models may differ for the phoebes because they prefer different habitat types and because the two species don't coexist on a broad scale in the contact zone.

The spatial and ecological relationships of the phoebes may be more similar to those of the skinks (Eumeces spp.) in Oklahoma (Costa et al. 2008), where E. obsoletus occurs in xeric habitat, E. fasciatus in deciduous forest. Costa et al. (2008) concluded that microhabitat availability across the climatic gradient in contact zone is likely the primary limiting factor. Although this result may be true for the phoebes as well, the EVI model predicted overlap that was fairly extensive in phoebes in the Great Plains (at least at coarse resolution), so increased abundances could make interspecific competition more important. However, the effects of competition can be subtle, and co-occurrence can be brief (Wiens 1977) or at low densities (Martin 1986). Distinguishing the effects of climate, competition, autecology, and other biotic causes can be challenging (Cadena and Loiselle 2007), but local-scale data may shed light on factors that affect distribution that are not discernable with broader-scale data (Guisan and Thuiller 2005, Wiens and Graham 2005).

\section{LOCAL SCALE}

Grassland is a habitat important to Say's Phoebe (Schukman and Wolf 1998) and originally abundant in the region (Kuchler 1974): this species is common on Cretaceous rock outcrops in the valley of the upper Smoky Hill River (Busby and Zimmerman 2001), an area represented in our study by the western part of cluster D and in native prairie throughout western Kansas (Sparks et al. 2005). Farther east, the ratio Say’s:Eastern was about equal at $99^{\circ} \mathrm{W}$ (cluster C); at $\sim 97^{\circ} \mathrm{W}$ (cluster A) Say's Phoebes were absent. In eastern areas, seemingly appropriate structures (buildings) in open country remain unused or are used occasionally by Eastern Phoebes (JMS, pers. obs.), even when these structures lie within the extensive grassland regions of the eastern Smoky Hills and Flint Hills of central Kansas.

In contrast, Eastern Phoebes selected nest sites along a habitat gradient from woodland streams to draws with sparse or no woodland, but they chose the former preferentially.
Nest-site selection may be a simple consequence of needing mud to form the base of its nest, food availability and foraging behavior, and/or concealment and protection associated with woodland habitat (Weeks 1994). However, Eastern Phoebes also reline nests previously built by Barn Swallows (Hirundo rustica), which occur in more open areas, and in which mud is not needed (JMS, pers. obs.). Woodlands are frequent, but not always necessary, in the immediate vicinity of Eastern Phoebe nests (Hill and Gates 1988, Schukman 2004).

Although potentially suitable sites may have been available in open country with little or no woodland, Eastern Phoebes did not use them consistently; they were used by Say's Phoebes or Barn Swallows or not at all. In Woods County, northwestern Oklahoma, an area lacking Say's Phoebes, Eastern Phoebes used nest sites (four bridges) in open country with no woodland nearby (Schukman 2004; JMS, pers. obs.). If competition from Say's Phoebes were an important limiting factor, northwest Oklahoma could extend the Eastern Phoebe's opportunities to breed via competitive release. However, these sites were used in only one or two of five years of observation, whereas nearby sites with woodland were occupied in all five years (JMS, pers. obs.). Although no breeding of Say's Phoebe has been reported from this county (Reinking 2004), the species occurs in this area as a spring migrant (JMS, pers. obs.; Sibley 2003). In an area of sympatry in west-central Kansas Schukman (1993) reported that a Say's Phoebe chased an Eastern Phoebe from a nest site and that another displaced a nesting Eastern Phoebe. However, he observed interspecific interactions only rarely and could attribute only one failure of an Eastern Phoebe nest to interference from Say's Phoebes. Hence competition from Say's Phoebe cannot be cited as a strong structuring factor in the Eastern Phoebe's distributional biology.

Because of the Eastern Phoebe's widespread but spotty occurrence in the western Great Plains, identifying its western distributional limit is challenging. Occurrences clearly decline from east to west, consistent with all ENM predictions at the continental extent and with climate-based ENMs at the contact-zone extent. However, the EVI-based ENM at the contact-zone extent showed potential for occurrence much farther west. Indeed, this species may be expanding more locally and regionally: in our study, Eastern Phoebes used 7 sites (4 in 2005, 2 in 2004, 1 in 2010) that were previously occupied by Say's Phoebe, whereas Say's Phoebe occupied only one site (2005) previously used by Eastern Phoebe, significantly different from random expectations (sign test, $P<$ $0.05)$. Breeding bird atlases show scattered occurrences of the Eastern Phoebe west of cluster D in Kansas (Busby and Zimmerman 2001) and in eastern Colorado (Kingery 1998) where isolated microhabitats exist in the more arid landscape. Increases in woody vegetation due to fire suppression or landuse changes in the Great Plains (Johnson 1994, Bratton et al. 1995, Coppedge et al. 2001) may provide additional nest habitat and increases in abundance. 
Models of climate change and its effects on future vegetation density suggest that moderate warming could initially increase vegetation but greater warming would reduce vegetation because of drought (Bachelet et al. 2001). Historically, during periods of drought, Say's Phoebe has expanded eastward in Nebraska (Sharpe et. al. 2001). In the early 1940s, after a severe decade-long drought and decrease of tree cover (Albertson and Weaver 1945), Say's Phoebe represented $82 \%$ of the total number of occurrences of phoebes $(n=51)$ in Valley County, Nebraska, at about $99^{\circ} \mathrm{W}$ longitude (McClure 1946), in contrast to a proportion of $15 \%(n=39)$ in Nebraska between $99^{\circ}$ and $100^{\circ}$ W from 1984 to 1989 (Mollhoff 2001). Therefore, future climate change may favor either species at different times, depending on the severity of warming and its effects on vegetation cover.

Reproductive success of the Eastern Phoebe in westcentral Kansas was similar to that in eastern Kansas, but the amounts of woodland habitat and density of birds in the former region were much less (Schukman 1993). From east to west, climate becomes more extreme (Wiens 1974), and climatic factors that affect habitat are probably important constraints limiting Eastern Phoebe populations (Brennan and Schnell 2007). The eastern limit of Say's Phoebe coincides with climatic gradients also, and we did not find this species in the buffered habitat used by its eastern counterpart. Preempting nest sites may favor the earlier-nesting Eastern Phoebe, but the climatic extremes at the western edge of its range may be the same conditions, in part, that regulate populations of the xeric-adapted Say's Phoebe throughout its range. Schukman (1993) found that in west-central Kansas the number of Say's Phoebe young fledged, as a percentage of eggs laid (44\%), was slightly lower than that of the Eastern Phoebe (45\%). Hence, in general, at least at the broader spatial scales we explored in this study, we see little in the way of a significant role of competition in structuring the distributions of these two species. Analyses of BBS estimates of population trends in light of factors that influence habitat use and survival, such as spread of invasive woody species, climate change, or interspecific competition, could provide a better understanding of the interrelationships and distribution limits of these closely related species.

\section{ACKNOWLEDGMENTS}

We thank Henry Armknecht, Ken Brunson, Greg Farley, Rob Fowler Terry and Sam Mannell, SeEtta Moss, Shannon Nilz, Mike Radar, Mark Robbins, Stan Roth, and Scott Seltman for field observations and Rhonda Houser and Shannon Nilz for GIS assistance. AL-N received graduate scholarship support from the Consejo Nacional de Ciencia y Tecnología (189216), México. ATP was supported by grants from Microsoft Research and the National Science Foundation.

\section{LITERATURE CITED}

Albertson, F. W., And J. E. Weaver. 1945. Injury and death or recovery of trees in a prairie climate. Ecological Monographs $15: 393-433$.
AOU. 1998. Check-list of North American birds, 7th ed. American Ornithologists' Union, Washington, DC.

Anderson R. P., A. T. Peterson and M. Gómez-Laverde. 2002. Using niche-based GIS modeling to test geographic predictions of competitive exclusion and competitive release in South American pocket mice. Oikos 98:3-16.

Anderson, R. P., D. Lew, and A. T. Peterson. 2003. Evaluating predictive models of species' distributions: criteria for selecting optimal models. Ecological Modelling 162:211-232.

ANDERSON, R. P., AND A. RAZA. 2010. The effect of the extent of the study region on GIS models of species geographic distributions and estimates of niche evolution: preliminary tests with montane rodents (genus Nephelomys) in Venezuela. Journal of Biogeography 37:1378-1393.

Bachelet, D., R. P. Neilson, J. M. Lenihan, and R. J. Drapek. 2001. Climate change effects on vegetation distribution and carbon budget in the United States. Ecosystems 4:164-185.

Bratton, G. F., F. R. Schaefer, And J. R. BRAndLE. 1995. Conservation forestry for sustainable Great Plains ecosystems, p. 211227. In S. R. Johnson and A. Bouzaher [EDS.], Conservation of Great Plains ecosystems: current science, future options. Kluwer Academic, Dordrecht, the Netherlands.

Brennan, S. P., AND G. D. Schnell. 2007. Multiscale analysis of tyrannid abundances and landscape variables in the Central Plains, USA. Wilson Journal of Ornithology 119:631-647.

Busby, W. M., AND J. L. Zimmerman. 2001. Kansas breeding bird atlas. University Press of Kansas, Lawrence, KS.

Cadena, C. D., AND B. A. Loiselle. 2007. Limits to elevational distributions in two species of emberizine finches: disentangling the role of interspecific competition, autoecology, and geographic variation in the environment. Ecography 30:491-504.

CooK, A. G. 1984. Birds of the desert region of Uintah, Utah. Great Basin Naturalist 44:584-620.

Coppedge, B. R., D. M. Engle, R. E. Masters, and M. S. Gregory. 2001. Avian response to landscape change in the fragmented southern Great Plains grasslands. Ecological Applications 11:47-59.

Costa, G. C., C. Wolfe, D. B. Shepard, J. P. Caldwell and L. J. VITT. 2008. Detecting the influence of climatic variables on species distributions: a test using GIS niche-based models along a steep longitudinal environmental gradient. Journal of Biogeography 35:637-646.

CunNingham, H. R., L. J. Rissler, AND J. J. APODACA. 2009. Competition at the range boundary in the slimy salamander: using reciprocal transplants for studies on the role of biotic interactions in spatial distributions. Journal of Animal Ecology 78:52-62.

DiXON, K. L. 1989. Contact zones of avian congeners on the southern Great Plains. Condor 91:15-22.

Ehrlich, P. R., D. S. Dobkin, ANd D. Wheye. 1988. The birder's handbook. Simon and Schuster, New York.

EMLEN, S. T., J. D. Rising, AND W. L. Thompson. 1975. A behavioral and morphological study of sympatry in the Indigo and Lazuli buntings of the Great Plains. Wilson Bulletin 87:145-179.

Guisan, A., AND W. Thuiller. 2005. Predicting species distribution: offering more than simple habitat models. Ecology Letters 8:993-1009.

Hijmans, R. J., S. E. Cameron, J. L. Parra, P. G. Jones, and A. JARVIS. 2005. Very high resolution interpolated climate surfaces for global land areas. International Journal of Climatology 25:1965-1978

HiLL, S. R., AND J. E. GATES. 1988. Nesting ecology and microhabitat of the Eastern Phoebe in the central Appalachians. American Midland Naturalist 102:313-324.

Johnson, W. C. 1994. Woodland expansions in the Platte River, Nebraska: patterns and causes. Ecological Monographs 64:45-84. 
KingerY, H. E. 1998. Colorado breeding bird atlas. Colorado Bird Atlas Partnership and Colorado Division of Wildlife, Denver.

KNOPF, F. L., AND M. L. ScOTT. 1990. Altered flows and created landscapes in the Platte River headwaters, 1840-1990, p. 47-70. In J. M. Sweeney [ED.], Management of dynamic ecosystems. Wildlife Society, West Lafayette, IN.

KuChleR, A. W. 1974. A new vegetation map of Kansas. Ecology 55:586-604.

MarTin, T. E. 1986. Competition in breeding birds: on the importance of considering processes at the level of the individual. Current Ornithology 4:181-210.

MAYR, E., AND R. J. O’HaRA. 1986. The biogeographic evidence supporting the Pleistocene forest refuge hypothesis. Evolution 40:55-67.

McClure, H. E. 1946. Phoebes in central Nebraska. Auk 63:211215.

McPeek, M. A., N. L. Rodenhouse, R. T. Holmes, ANd T. W. SHerry 2001. A general model of site-dependent population regulation: population-level regulation without individual-level interactions. Oikos 94:417-424.

MoLLhoff, W. J. 2001. The Nebraska breeding bird atlas: 1984-1989. Nebraska Game \& Parks Commission, Lincoln, NE.

MurPhy, H. T., AND J. LOVETT-Doust. 2007. Accounting for regional niche variation in habitat suitability models. Oikos 116:99-110.

Peterson, A. T. 2003. Projected climate change effects on Rocky Mountain and Great Plains birds: generalities of biodiversity consequences. Global Change Biology 9:647-655.

Peterson, A. T., J. Soberón, ANd V. SÁnchez-Cordero. 1999. Conservatism of ecological niches in evolutionary time. Science 285:1265-1267.

Peterson, A. T., M. Papes, And M. Eaton. 2007. Transferability and model evaluation in ecological niche modeling: a comparison of GARP and Maxent. Ecography 30:550-560.

Peterson, R. A. 1995. The South Dakota breeding bird atlas. South Dakota Ornithologists' Union, Jamestown, SD.

Phillips, S. J., R. P. Anderson, And R. E. Schapire. 2006. Maximum entropy modeling of species geographic distributions. Ecological Modelling, 190:231-259.

Pieplow, N. D., T. Leukering, And E. Coley. 2008. An apparent hybrid Black $\times$ Eastern Phoebe from Colorado. Western Birds 39:209-219.

RISING, J.D. 1983. The Great Plains hybrid zones. Current Ornithology 1:131-157.

Rising, J. D. 1996. The stability of the oriole hybrid zone in western Kansas. Condor 98:658-663.

REINKING, D. L. 2004. Oklahoma breeding bird atlas. University of Oklahoma Press, Norman, OK.

Rumble, M. A., C. H. Sieg, D. W. UResk, and J. Javersak. 1998 Native woodlands and birds of South Dakota: past and present Research Paper RMRS-RP-8. U.S. Forest Service, Rocky Mountain Research Station, Fort Collins, CO.
Sauer, J. R, J. E. Hines, and J. Fallon. 2008. The North American Breeding Bird Survey, results and analysis 1966-2007, version 5.15.2008. U.S. Geological Survey, Patuxent Wildlife Research Center, Laurel, MD.

SchuKMAN, J. M. 1993. Breeding ecology and distribution limits of phoebes in western Kansas. Kansas Ornithological Society Bulletin 44:25-29.

Schukman, J. M. 2004. Confirmed nesting of Say's Phoebe in Harper County, Oklahoma. Oklahoma Ornithological Society Bulletin 37:7-8.

Schukman, J. M., And B. O. Wolf. 1998. Say's Phoebe (Sayornis saya), no. 374. In A. Poole and F. Gill [EDS.], The Birds of North America. Birds of North America, Inc., Philadelphia.

Sharpe, R. S., W. R. Silcock, AND J. G. Jorgensen. 2001. Birds of Nebraska; their distribution and temporal occurrence. University of Nebraska Press, Lincoln, NE

SiBLEY, D. A. 2003. Field guide to the birds of western North America. Knopf, New York.

SOBERÓN, J., AND A. T. PETERSON. 2005. Interpretation of models of fundamental ecological niches and species' distributional areas. Biodiversity Informatics 2:1-10.

Sparks, R. A., D. J. Hanni And M. McLachlan. 2005. Section-based monitoring of breeding birds within the Shortgrass Prairie Bird Conservation Region (18). Rocky Mountain Bird Observatory, Brighton, $\mathrm{CO}$.

STEWART, R. E. 1975. Breeding birds of North Dakota. Tri-College Center for Environmental Studies, Fargo, ND.

Stockwell, D. R. B., AND D. Peters. 1999. The GARP modeling system: problems and solutions to automated spatial prediction. International Journal of Geographic Information Science 13:143-158.

SwENSON, N. G. 2006. GIS-based niche models reveal unifying climatic mechanisms that maintain the location of avian hybrid zones in a North American suture zone. Journal of Evolutionary Biology 19:717-725.

WARren, D. L., R. E. Glor, AND M. TurelLI. 2008. Environmenta niche equivalency versus conservatism: quantitative approaches to niche evolution. Evolution 62:2868-2883.

Warren, D. L., R. E. Glor, And M. Turelli. 2010. ENMTools: a toolbox for comparative studies of environmental niche models. Ecography 33:607-611.

WeEks, H. P. JR. 1994. Eastern Phoebe (Sayornis phoebe), no 94. In A. Poole and F. Gill [EDS.], The Birds of North America. Academy of Natural Sciences, Philadelphia.

WIENS, J. A. 1974. Climatic instability and the "ecological saturation" of bird communities in North American grasslands. Condor 76: $385-400$.

WIENS, J. A. 1977. On competition and variable environments. American Scientist 65:590-597.

WIENS, J. J., AND C. H. GRAHAM. 2005. Niche conservatism: integrating evolution, ecology, and conservation biology. Annual Reviews of Ecology, Evolution, and Systematics 36:519-539. 